\title{
Academic Learning Outcome And Creative Thinking Skills On Projectile Motion Topic
}

\author{
John Rafafy Batlolona ${ }^{1}$, Natcha Mahapoonyanont ${ }^{2}$ \\ ${ }^{1}$ Teacher Professional Education Study Program, Teacher Training and Education Faculty, \\ Pattimura University, Indonesia \\ ${ }^{2}$ Educational Faculty, Thaksin University,Songkhla Campus, Thailand \\ e-mail: johanbatlolona@gmail.com¹, natcha.m@hotmail.com²
}

\begin{abstract}
$P B L$ is one of the constructive learning models. Therefore, the purpose of this study was to find out whether PBL was more effective in enhancing academic learning outcomes and creative thinking skills with different classes. This research was begun by compiling instruments, carrying out the learning process, analyzing data, and presenting it in the form of reports. The results showed that the average value of student learning achievement was 73.29 in the experimental class and 74.40 in the control class. This average value and the hypothesis was then tested by independent sample $T$ test. The right tailed T-test was used to find out whether the learning achievements of students taught through PBL were higher than those taught through conventional method. Through the T-test with the help of SPSS, the results of $t_{\text {count }} 0.514<t_{\text {table }} 1,670$. From the result of the analysis it can be concluded that the learning achievement of the experimental class students is smaller or equal to the control class. The data on creative skills were tested nonparametric analysis, the Mann-Whitney test because data was not normally distributed. Through the Mann-Whitney analysis with the assistance of SPSS, it was obtained $z$ values for creative thinking skills 5,608> 1,65 for creative thinking skills data. This means that the creative skills of students taught by PBL were higher than those taught conventionally were.
\end{abstract}

Keywords: academic learning outcomes, creative thinking skills, PBL

\section{Introduction}

Learning is one of the most important aspects in implementing education. In the learning process, teachers are expected to have good academic competencies. Therefore, the teacher must have extensive knowledge of learning models, the condition of student and effective and meaningful learning so that students can be independent in their learning. Mastery of basic competencies and advanced competencies is very influential on student academic learning outcomes (Leasa \& Corebima, 2017). The process and results of learning are very dependent on the teacher including competencies, teaching materials, teaching characteristics and skills and learning situations.

In addition to the aspects relating to the existing learning situation, learning experts have designed humanistic learning to improve the quality of the process and the learning outcomes of constructivist that can enhance student-learning activities. Changes in the 21st century paradigm have focused on student-centered learning (Agrahari, 2016; Williams, 2017). When interacting in class, the teacher must maximally create a learning environment that can make students to learn, encourage thinking skills, and provide opportunities for students to play an active role in constructing the concepts learned. This kind of pattern must be changed with discussion of knowledge, seeking (inquiry) and finding that there is an increase in the understanding of students' concepts.

Learning activities should prepare students who have the ability to solve problems, be critical and creative in conditions that are globally insightful in the 21 st century. Creative thinking skills are needed to integrate theories learned in school with events in daily life (Awaludin, Kurniawan \& Hartuti , 2017). Students who have good creative thinking skills will be able to solve better physics problems (Wartono, Diantoro, Batlolona, 2018).

This indicates that learning physics is not only done by memorizing but also through a series of scientific activities such as a scientist. Physics education is directed to find out and act so that it can help students to gain a deeper understanding of nature around. One learning model that can facilitate students in solving natural problems around is Problem 
Based Learning (PBL) (Argaw, Haile, Ayalew, Kuma, 2017). This model relates to problems while training the skills of creative thinking skills of students to improve academic learning outcomes (Batlolona, 2018). The stages of PBL include formulating problems and making hypotheses, designing experiments, conducting investigations, collecting data, interpreting data, making conclusions, presenting, discussing, and making reports (Arends, 2012). This situation shows that PBL models are expected to improve students' understanding of what they are learning so students can apply it in real life (Ayyildiz \& Tarhan, 2017; Batlolona, Baskar \& Leasa, 2018).

PBL can be applied if it is supported by a constructive learning environment (Inel \& Balim, 2010). Constructivist learning environments are associated with cognitive flexibility that can help students learn to identify root causes or sources of major problems that have an impact on other problems (Yew \& Goh, 2016). Learning activities like this can help in improving critical thinking skills. The flexibility of cognition represents the subject matter in an effort to understand the complexity associated with the domain of knowledge. Cognitive flexibility can be increased by providing opportunities for students to give their ideas that illustrate their understanding of the problem. Cognitive flexibility can foster divergent thinking creativity in presenting problems (Ritter \& Mostert, 2017). Divergent thinking is one of the characteristics of creative thinking (Mumford \& Mcintosh, 2017). The purpose of this study was to determine whether PBL was more effective in enhancing academic learning outcomes and creative thinking skills with different classes.

\section{Method}

\section{a. Research Design}

The research design used in this study was a quasi-experimental design because the variables could not be perfectly controlled so that it was not enough to be called true experimental research. This study used a posttest only control group design (Creswell \& Clark, 2007).

The experimental class was given special treatment in the form of learning with Problem Based Learning (PBL) models while learning in the control class took place conventionally. After the treatment, the two classes were tested with the same test as the final test (posttest).

\section{b. Population and Research Samples}

The population in this study were students of class X Senior High school 8 Malang. The determination of the sample in the study was through by purposive sampling, namely sampling with certain considerations, to see the characteristics of the population. Based on the information obtained directly from teachers who teach class $X$, classes $X_{5}$ and $X_{4}$ the student of thoses classes have almost similar characteristics (based on the average learning achievement of Physics and learning activities). Furthermore, a statistical equality test was conducted based on the formative values of the previous material to strengthen the equality of the three classes.

\section{c. Data Collection Instruments}

The measurement instruments used in this study were: (a) the sheet of process implementation observation that was used to obtain data on the implementation of the lesson plan. (b) the test that was used to obtain data on creative thinking skills and student achievement, and (c) documentation guidelines that was used to obtain data regarding the initial ability of student learning achievement from the formative value of the previous material.

Before it was applied, the validity of test instrument was tested in advance, which included the validity of content, constructs and field. Content and construct validity were carried out by physics and theoretical physics experts. Field validity was carried out to 120 respondents, namely regular students in several schools in Malang City. The implementation of field trials was conducted to look for discrimination power, validity, level of difficulty, and reliability of the items before the experimental research was conducted. 


\section{d. Data Analysis}

Data analysis was an activity carried out after data from the data source was collected. Testing the hypothesis in this study consisted of three types, namely testing the hypothesis of learning achievement, critical thinking skills, and creativity. Testing the hypothesis of the three dependent variables could only be determined after the prerequisite test. This prerequisite test was conducted to find out whether the data was normally distributed or not and homogeneous or not so that statistical techniques could be used. If the data was normally distributed, parametric statistical techniques were used to test the hypothesis, namely the T-test. If the data was not normally distributed, it must use nonparametric statistical techniques, namely the Mann-Whitney U-test. Therefore, the data analysis prerequisite test was carried out before a hypothesis test was carried out as follows.

\section{e. Prerequisite Test for Data Analysis}

This prerequisite test must be done before testing the hypothesis. This test included the normality test and homogeneity test. The normality test was done to find out whether the data analyzed was normally distributed or not. One formula that could be used to test the normality of sample data was the Chi Square test. The normality testing of the data in this study was carried out with the assistance of SPSS 16.0 for Windows and manually checked.

\section{Homogeneity Test}

Variance homogeneity tests were needed before we compared two or more groups so that the differences were not caused by differences in baseline data (the inhomogeneity of the groups compared). This test was used to determine whether the two groups had the same level of data variance or not. To test the similarity of two data variances from the two groups, the F test was used.

\section{Hypothesis testing}

Hypothesis testing in this study was carried out on three variables, namely learning achievement, critical thinking skills, and creativity. The hypothesis test of learning achievement was conducted to find out whether the experimental class student achievement was higher than the learning achievement of the control class students. Hypothesis testing techniques can be determined after the prerequisite test. If the data was normally distributed, parametric statistical techniques were used, namely the one-tailed t test. If the data was not normally distributed, nonparametric statistical techniques were used, namely the MannWhitney $\mathrm{U}$ test. Both of these tests can be described as follows.

\section{T-test}

After the prerequisite test was carried out and it was proven that the data was normally distributed, then this T-test can be used as a hypothesis test, namely the one-tailed T-test because the researcher has favored one of the two research groups, namely the class that was taught using the Problem Based Learning model. This T-test could also be done with the assistance of the SPSS 16.0 for windows program using an independent sample $t$ test.

\section{Mann-Whitney Test (U Test)}

If the results of the normality test showed that the data was not normally distributed, then the hypothesis test used was the one-party Mann-Whitney $U$ test. This $U$ test was used to test the comparative hypothesis of two independent (unrelated) samples if the data was ordinal. If the data was in the form of an interval, it must first be converted into ordinal data. The $U$ test formula can be seen in Siegel's 1985 book 151. If the $z$ value obtained from the calculation results was greater than the critical value, $\mathrm{H} 1$ is accepted. The amount of the critical value $z$ for one tailed analysis is 1.65 . 


\section{Results and Discussion}

\section{a. Cognitive Learning Outcomes}

The results of data analysis regarding learning achievement variables are as follows.

Description of Learning Achievement Data

Student learning achievement data is the value obtained by students after being given treatment obtained from the learning achievement test. Description of student learning achievement data can be seen in Table 1.

Table 1. Description of Learning Achievement Data

\begin{tabular}{lcccc}
\hline Class & $\begin{array}{c}\text { The highest } \\
\text { score }\end{array}$ & $\begin{array}{c}\text { The Lowest } \\
\text { score }\end{array}$ & $\begin{array}{c}\text { The Average } \\
\text { score }\end{array}$ & $\begin{array}{c}\text { Standard } \\
\text { Deviation }\end{array}$ \\
\hline Experiment & 88 & 60 & 73,29 & 8,34 \\
Control & 88 & 56 & 74,40 & 7,24 \\
\hline
\end{tabular}

Based on Table 1, it can be seen that the average score obtained by the experimental class (73.29) is almost the same as the average value obtained in the control class (74.40). Furthermore, the data on the initial abilities of students in the experimental and control classes were tested for normality and homogeneity as a prerequisite for hypothesis testing.

\section{Prerequisite Test for Analysis}

Normality test

The normality test results of the learning outcomes of experimental class and control class students using SPSS 16.0 for windows software can be seen in Table 2 .

Table 2. Data on Normality Test of Student Cognitive Learning Outcomes

\begin{tabular}{lcccc}
\hline \multicolumn{1}{c}{ Class } & $\mathbf{N}$ & $\overline{\boldsymbol{x}}$ & Std deviation & Asymp-Sig \\
\hline Experiment & 28 & 73,29 & 5,15 & 724 \\
Control & 25 & 74,40 & 5,01 &, 758 \\
\hline
\end{tabular}

Based on data analysis through SPSS 16.0 for windows, the results of the normality test of the data on the experimental achievement and control class are normal. This can be seen from the sig value $(p)$ of the experimental class, which is 0.724 and 0.758 for the control class. This value is greater than the significance level of 0.05 so that it can be concluded that both the data for the experimental class and the controls were equally normally distributed.

Homogeneity Test

The homogeneity test results of the learning outcomes of experimental class and control class students using SPSS 16 software can be seen in Table 3.

Table 3. Data on Homogeneity Test of Student Cognitive Learning Data

\begin{tabular}{lccccc}
\hline \multicolumn{1}{c}{ Class } & $\overline{\boldsymbol{x}}$ & $\mathbf{N}$ & $\mathbf{F}_{\text {count }}$ & $\mathbf{F}_{\text {Table }}$ & Asymp-Sig \\
\hline Experiment & 73,29 & 28 &, 275 & 4,00 &, 432 \\
Control & 74,40 & 25 &, 270 \\
\hline
\end{tabular}

Based on the analysis of data through SPSS for Windows 16, the results of the posttest homogeneity test results of the experimental and control class learning achievements provide a significance of $0.432>0.05$. It can be concluded that the ability of the experimental class and control students is homogeneous.

\section{Hypothesis testing}

Based on the analysis prerequisite test, it can be seen that the distribution of data in both the experimental class and the posttest control results of learning achievement was 
normally distributed. Therefore, to test the research hypothesis, parametric tests can be used. In accordance with the research title, that was to look for the effectiveness of PBL on learning achievement and research hypothesis, which stated that the experimental class learning achievement was higher than the control class, then the T-test was used by onetailed, namely the right tailed. The T-test formula was of two types, namely separated variance and polled variance. To find out which $T$ test that was more suitable, it can be reviewed based on the number of samples between the control and the experimental class and seen based on the homogeneity of the data. The test results of the learning achievement hypothesis of experimental and control class using SPSS 16.0 for windows software can be seen in Table 4.

Table 4. Cognitive Learning Outcomes Hypothesis Test Data

\begin{tabular}{lccccc}
\hline \multicolumn{1}{c}{ Class } & $\overline{\boldsymbol{x}}$ & $\mathbf{N}$ & $\mathbf{T}_{\text {count }}$ & $\mathbf{t}_{\text {Table }}$ & Asymp-Sig \\
\hline Experiment & 73,29 & 30 & 0,514 & 1,670 & 0,610 \\
Control & 74,40 & 28 & 0,510 & \\
\hline
\end{tabular}

Based on Table 4, it can be seen that the Asymp-Sig value is $0.610>0.05$. This means there was no difference between the learning achievement of the experimental and control classes. Based on the value of $t_{\text {count }}$ is 0.514 and $t_{\text {table }}$ is 1.670 so that $t_{\text {count }}<t_{\text {table }}$ and the initial hypothesis $\left(\mathrm{H}_{0}\right)$ was accepted. It can be concluded that the learning achievement of the experimental class was smaller or equal to the control class even though it has been given different treatment.

\section{Creative Thinking Skills}

The results of data analysis regarding the variables of creative thinking skills are as follows.

\section{Data Description Creative Thinking Skills}

The data on students' creative thinking was the value obtained by students after being given the treatment obtained from creative thinking tests. The data description of students' creative thinking skills can be seen in Table 5 .

Table 5. Data Description of Creative Thinking Skills

\begin{tabular}{lcccc}
\hline Class & $\begin{array}{c}\text { The highest } \\
\text { score }\end{array}$ & $\begin{array}{c}\text { The Lowest } \\
\text { value }\end{array}$ & $\begin{array}{c}\text { The Average } \\
\text { value }\end{array}$ & $\begin{array}{c}\text { Standard } \\
\text { Deviation }\end{array}$ \\
\hline Experiment & 4 & 2 & 3 & .83 \\
Control & 2 & 1 & 1 & .50 \\
\hline
\end{tabular}

Based on Table 5, it is known that the average value obtained by the experimental class $(0.83)$ is almost the same as the average value obtained in the control class $(0.50)$. Furthermore, the data on the initial abilities of students in the experimental and control classes were tested for normality and homogeneity as a prerequisite for hypothesis testing.

Prerequisite Test for Analysis

Normality test

The normality test results of the creative thinking skills value of students in the experimental and control class was analyzed by using SPSS 16.0 for windows software. It can be seen in Table 6.

Table 6. Normality Test Results of Student Creative Thinking Skills

\begin{tabular}{lllcc}
\hline \multicolumn{1}{c}{ Class } & $\mathbf{N}$ & $\overline{\boldsymbol{x}}$ & Std deviation & Asymp-Sig \\
\hline Experiment & 28 & 2 & .83 &, 002 \\
Control & 25 & 1 & .50 &, 000 \\
\hline
\end{tabular}


Based on the data analysis using SPSS for Windows 16.0 for Windows, the normality test results of the learning achievement data on the experimental and control class are abnormal. This can be seen from the value of sig. $(P)$ the experimental class is 0.002 and 0.000 for the control class. This value is smaller than the significance level of 0.05 so that it can be concluded that both data for the experimental and the control class were equally not normally distributed.

\section{Hypothesis testing}

Based on the analysis prerequisite test, it can be seen that the data distribution of creative thinking posttest results in both the experimental and control classes was not normally distributed. Therefore, the nonparametric test was used to test the research hypothesis. The nonparametric test chosen was a U-test or a one-tailed Mann-Whitney. Based on the collected data, the $U$ test was suitable to be applied to the data in the form of scores.

Hypothesis results of experimental and control classes creative thinking skills using SPSS 16.0 for windows software can be seen in Table 7.

Table 7. Hypothesis Test Results of Creative Thinking Skills

\begin{tabular}{cccccc}
\hline \multicolumn{1}{c}{ Class } & $\overline{\boldsymbol{x}}$ & $\mathbf{N}$ & $\mathbf{Z}_{\text {count }}$ & $\mathbf{Z}_{\text {score }}$ & Asymp-Sig \\
\hline Experiment & 37,50 & 30 & 5,608 & 1,650 & 0,000 \\
Control & 15,24 & 28 & 5,600 \\
\hline
\end{tabular}

Based on Table 7 above, the data on critical thinking skills obtained by the value of $\mathrm{Z}_{\text {count }}$ is 5.608> 1.650. This means that the initial hypothesis is rejected and the alternative hypothesis is accepted, so it can be concluded that the creative thinking skills of the experimental class were higher than the control class.

\section{Problem Based Learning (PBL) Process}

Problem based learning ( $P B L)$ is a learning model that is oriented to the theoretical framework of constructivism (Davidson \& Major, 2014). The focus of PBL lies in the problem chosen so that it not only requires students to learn concepts related to the problem but also the scientific method for solving the problem (Akcay, 2009).

PBL process carried out by researchers could be said to be good. This could be seen from the process implementation sheet, which stated that $80 \%$ of the learning scenarios had been implemented. However, based on the process implementation sheet, it could also be seen that there were two steps of activities that were still not well implemented. The two teacher activities that had not yet been carried out were giving practice questions at the end of the lesson along with their discussion and giving home assignments along with their discussion. Both of these activities were very important to be applied in learning Physics. Even though PBL syntax did not not include problem training, it should automatically be given questions and homework because this activity was one way to indirectly apply Physics concepts to daily life.

\section{PBL in Improving Learning Achievement}

PBL effectiveness in improving learning achievement can be said to be quite good. This can be seen from the experimental class average that increased from 64.89 to 73.29 after being treated. However, when compared with the control class, which has an average value of 74.40 with conventional learning, PBL cannot be said to be more effective in improving student learning achievement.

Based on research conducted by Batlolona, Wartono, Diantoro (2018) in their research entitled Problem based Learning (PBL) to improve physics learning achievement and creative thinking skills, it was written that PBL can improve physics learning achievement and creative thinking ability. The results of this study were not suitable for physics learning achievement data, which stated that physics learning achievements obtained by students taught with PBL were the same as conventional learning. The first possible factor was that 
students equipped themselves with additional learning activities at home with the aim of training their physics abilities. Learning applied by subject teachers as a whole was almost the same as physics learning applied by researchers, it could be said that the learning applied by subject teachers had been grounded.

The second possible factor was that the researchers rarely gave practice questions at the end of the meeting during the study. However, the researchers always gave home assignments as training questions from the physics concepts learned at school. Giving practice questions at the end of a meeting that was rarely done by the researchers was due to insufficient time. The learning process usually only lasts until a joint conclusion was reached that was followed by the time bell rings out. The researchers assumed that these two factors lead to conclusions from data analysis that the results of student learning outcomes taught by PBL were smaller or equal to students taught conventionally.

\section{PBL in Enhancing Creative Thinking Ability}

Based on the data and data analysis, the average value of students' creative thinking abilities taught with PBL is higher than conventional learning. The results of data analysis using the Mann-Whitney $U$ test showed that the creative thinking abilities of students taught by PBL were higher than those taught conventionally were.

Researchers assumed this result because PBL was more systematic. The experimental method that the majority carried out by researchers during the research was one way of planting a good concept. This caused the conceptual knowledge of students taught by PBL was deeper than control class students was. In addition, student worksheets used by students with PBL were more focused in helping students determine the problems to be sought through experiments and obtain an understanding of physics concepts through these experiments. Therefore, PBL should be carried out. If professional teachers applied PBL, researchers assumed that the value of learning achievement, critical thinking skills, and creative students taught through PBL as the three dependent variables will be higher than the value of students with conventional learning even though it has been grounded.

\section{Conclusions and Suggestions}

The implementation of the PBL model could be said to be well implemented. This could be seen from the results of the process of implementation, which showed that $80 \%$ of the learning process was carried out. Based on the results of the implementation process, it could also be seen that there were steps or learning activities that should not be left behind by researchers when conducting research but these steps were not implemented. As a result, the research results for student achievement between the experimental class and the control group were not different. The important steps in the research process that could not be done well was giving assignments and discussions, and homework. In fact, physics learning was very important. Other information is, 1) there was no difference between the experimental and control classes, 2) there was a significant difference between the experimental and control classes for the data of students' creative thinking skills.

The PBL model was suitable on material that required many experiments. The advantages of PBL that emphasized problems can help students in directing activities that must be done during the learning process. In addition, by knowing the root of the problem, understanding the concept will be more profound. For other researchers who wish to continue this research, the thing that must be considered in its implementation is to increase the amount of time and energy by forming better Teaching team that were more supervised intensively in its learning activities. The advantage of this research with previous research was to explore students' creative ideas in physics learning on the projectile motion topic. Because this material was still considered difficult by students, therefore students were more facilitated with PBL to be more active in expressing original creative ideas that were rarely considered by others to encourage the results of their academic learning. 


\section{References}

Agrahari, R. (2016). The Nature of Educational Reform and Change: From Teacher-centered to Student-centered learning. Educational Quest: An Int. J. of Education and Applied Social Sciences, 7(2), 133-139.

Akcay, B. (2009). Problem-Based Learning in Science Education. Journal of Turkish Science Education, 6(1), 26-36.

Arends, R. 2012. Learning to Teach. New York: The Me Graw-Hill Company.

Argaw, A. S., Haile, B. B., Ayalew, B. T., \& Kuma, S. G. (2017). The Effect of Problem Based Learning (PBL) Instruction on Students' Motivation and Problem-Solving Skills of Physics. EURASIA Journal of Mathematics Science and Technology Education, 13(3), 857-871.

Awaludin, A. A. R., Kurniawan, I., \& Hartuti, P. M. (2017). Junior High School Student's Reflective Thinking Process in Problem Solving Viewed from Learning Creativity. Jurnal Pendidikan Indonesia, 6(2), 154-162.

Ayyildiz, A., \& Tarhan, L. (2017). Problem-Based Learning in Teaching Chemistry: Enthalpy Changes in Systems. Research in Science \& Technological Education , 36(1), 35-54.

Batlolona, J. R. (2018). Model Mental Dan Keterampilan Berpikir Kreatif Fisika Siswa Melalui Model Pembelajaran Problem Based Learning (PBL) Pada Materi Elastisitas. Pascasarjana Universitas Negeri Malang. Tesis tidak di publikasikan.

Batlolona, J. R., Baskar, S., \& Leasa, M. (2018). Representasi Internal Mahasiswa Pada Topik Konveksi Air. KEGURU: Jurnal IImu Pendidikan Dasar, 2(2), 211-221.

Cresswell \& Clark. 2007. Designing and Conducting Mixed Methods Research. United States of Amerika: Sage Publication, Inc.

Inel, D., \& Balim, A. G. (2010). The Effects of Using Problem-Based Learning In Science And Technology Teaching Upon Students' Academic Achievement and Levels of Structuring Concepts. Asia-Pacific Forum on Science Learning and Teaching, 11(2), 1-23.

Leasa, M., \& Corebima, A. D. (2017). The effect of numbered heads together (NHT) cooperative learning model on the cognitive achievement of students with different academic ability. IOP Conf. Series: Journal of Physics: Conf. Series, 795(012071), 110.

Mumford, M., \& Mcintosh, T. (2017). Creative Thinking Processes: The Past and the Future. The Journal of Creative Behavior, 51(4), 317-322.

Ritter, S. M., \& Mostert, N. (2017). Enhancement of Creative Thinking Skills Using a Cognitive-Based Creativity Training. Journal of Cognitive Enhancement, 1, 243-25.

Wartono, W., Diantoro, M. \& Batlolona, J. R. (2018). Influence of Problem Based Learning Model on Student Creative Thinking on Elasticity Topics A Material. Jurnal Pendidikan Fisika Indonesia, 14(1), 32-39.

Williams, M. K. (2017). John Dewey in the 21st Century. Journal of Inquiry \& Action in Education, 9(1), 91-102.

Yew, E. H. J., \& Goh, K. (2016). Problem-Based Learning: An Overview of its Process and Impact on Learning. Health Professions Education, 2, 75-79. 